\title{
LITHOLOGICAL CHARACTERISTICS OF THE UPPERMOST TERRIGENOUS DEVONIAN COMPLEX IN ESTONIA
}

\author{
Anne KLEESMENT
}

Eesti Teaduste Akadeemia Geoloogia Instituut (Institute of Geology, Estonian Academy of Sciences), Estonia pst. 7, EE-0001 Tallinn, Eesti (Estonia)

Presented by D. Kaljo

Received 25 April 1995, accepted 8 June 1995

Abstract. In Estonia the uppermost terrigenous complex of Middle Devonian (Givetian) age is represented by light, mostly whitish-, yellowish-, and pinkish-grey fine-grained, weakly to medium-cemented cross-bedded sandstones, containing grey, reddish-brown or mottled siltstone and clay interlayers. In regional stratigraphy this part of the sequence comprises three stages (from the base): Burtnieki, Gauja, and Amata. The cyclic structure of the sequence has permitted us to distinguish smaller subdivisions. Thus, in the Burtnieki Stage three successive units, Härma, Koorküla, and Abava beds, have been established. The Gauja Stage comprises the Sietin and Lode members. In this paper a lithological-mineralogical characterization of all above units and criteria for their distinction in sections are given.

Key words: Devonian, lithostratigraphy, mineralogy, heavy transparent allothigenic minerals.

\section{INTRODUCTION}

In terms of local stratigraphy the interval studied comprises the Burtnieki, Gauja, and Amata regional stages (total thickness up to $200 \mathrm{~m}$ ) corresponding to the Givetian (Middle Devonian) and occurring in southeastern Estonia. Relatively widespread is the Burtnieki Stage. In the total extent the sequence studied is represented in the southeasternmost part of Estonia and is penetrated by only rare boreholes (Fig. 1). The Burtnieki Stage has always belonged to the Middle Devonian. An interval, at present corresponding to the Gauja and Amata stages, was initially distinguished by Gross $(1940,1942)$ as a Middle Devonian unit. Since the 1950s, however, it was assigned to the Upper Devonian Frasne Stage (Обручев, 1951; Марк \& Паасикиви, 1960; Сорокин, 1981; Куршс, 1975, 1992; Rzhonsnitskaya, 1988). Basing on the conodont scale, the Middle and Upper Devonian boundary has lately been shifted upwards (Klapper et al., 1987). According to the correlation chart of the East European Platform (Ржонсницкая \& Куликова, 1990), this boundary falls between the Timan and upperlying Sargajevo stages, corresponding in local stratigraphy to the boundary between the Amata and Plavinas stages (Mark-Kurik, 1993a, 1993b). However, it should be noted that the index species of conodonts are not known from the East European Platform. 


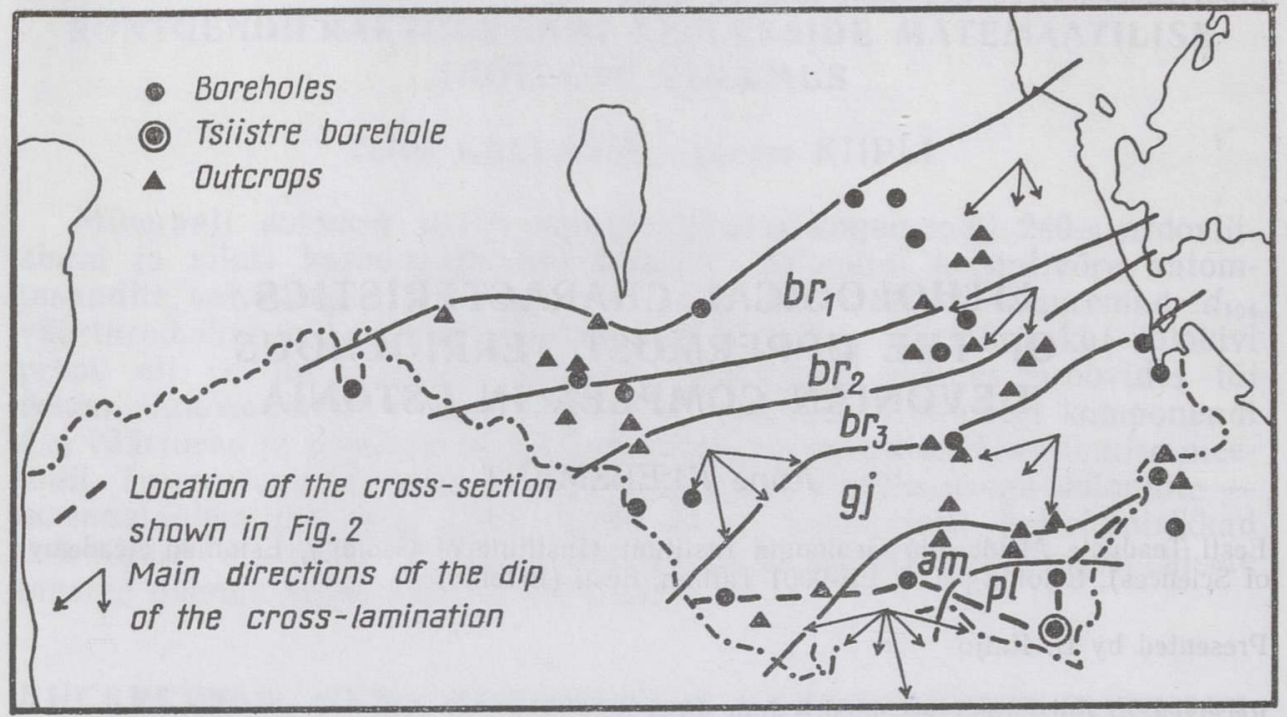

Fig. 1. Map showing the location of the studied sections and the distribution of stratigraphical units.

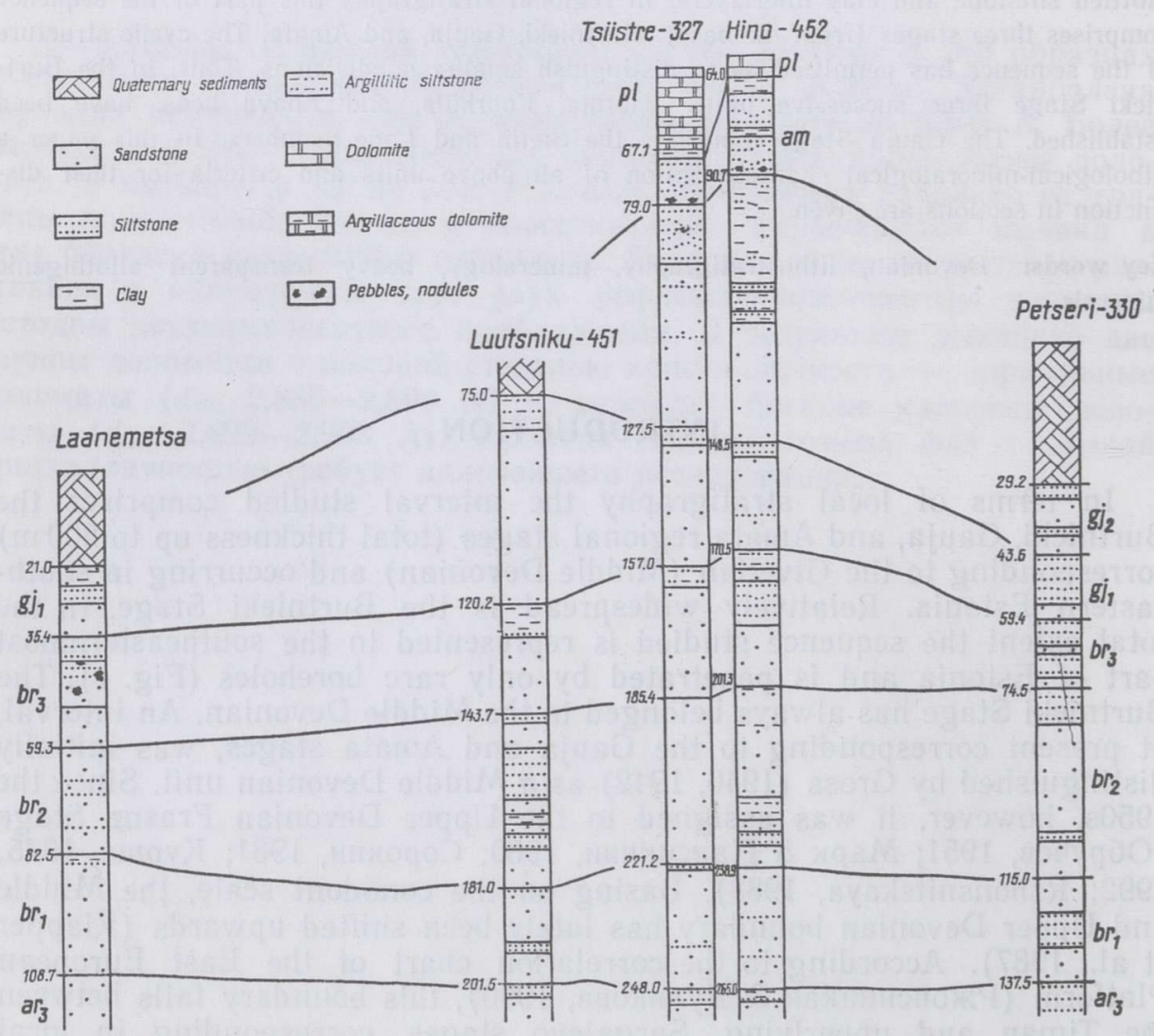

Fig. 2. Stratigraphical cross-section from Laanemetsa (west) to Petseri (east). Location see Fig. 1. 
The Burtnieki Stage was separated by E. Mark-Kurik from the Tartu Stage in 1958 (Mapk, 1958), although as an independent unit it occurred already in the scheme of Gross (1942; Table 1). The type section is situated in northern Latvia on the bank of the Salaca River in the region of Mazsalaca, $12 \mathrm{~km} \mathrm{NW}$ of Lake Burtnieki. In Estonia the stage is distributed in the southeastern area, its total thickness ranges from 60 to $94.5 \mathrm{~m}$. The maximum thickness has been recorded in the southernmost part of the territory (Tsiistre, Hino; Figs. 1,2). The stage is drilled through by numerous boreholes, abundant are natural exposures, quite many of which have a height of $5-10 \mathrm{~m}$ and more. Several outcrops (Karksi, Härma, Koorküla, Essi, etc.) are known as localities of fossil fishes.

The Burtnieki Stage is mainly represented by light (white, yellowish, pinkish, and greyish-brown) fine-grained medium- to weakly cemented cross-bedded sandstones, which contain siltstone and clay interlayers. The stage lies everywhere on the Tarvastu Beds of the Aruküla Stage $\left(a_{3}\right)$. The topmost layer of the Tarvastu Beds is, as a rule, represented by reddish or variegated (violet-grey to reddish-brown) siltstones, which are overlain by loose white, yellowish-, brownish- or violet-grey poorly sorted sandstones. The lowermost 1-m-thick layer of the Burtnieki Stage contains locally strongly patchy carbonate cement. The upper clayey-silty complex

Table 1

History of the stratigraphical definition of the uppermost terrigenous part of the Devonian

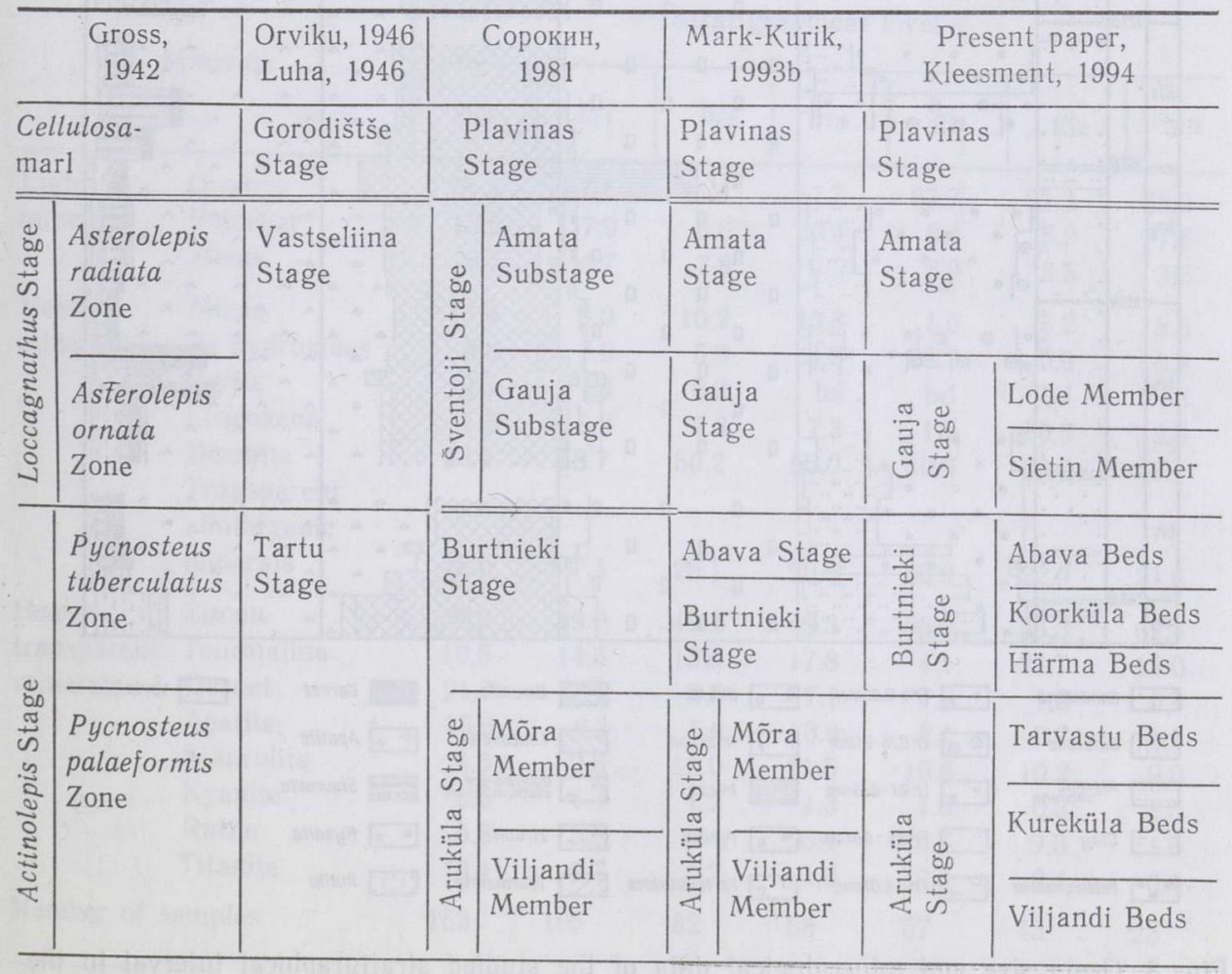

Middle/Upper Devonian boundary. 
of the Burtnieki Stage is overlain by light grey or yellowish sandstones of the Gauja Stage, which contain often abundantly carbonate cement on the contact level. However, in Estonia the major part of the Burtnieki Stage is distributed in the outcrop area with an incomplete sequence (Fig. 1).

In the Burtnieki Stage three succeeding cyclic complexes are recorded, which begin with relatively coarse-grained sandstones and end with clayey silt layers. These complexes are observed in all Estonian sections and serve as a basis for the distinction of three units: Härma ( $\mathrm{br}_{1}$, lower), Koorküla $\left(\mathrm{br}_{2}\right.$, middle), and Abava ( $\mathrm{br}_{3}$, upper) beds (Figs. 2, 3). The lithology and mineralogy of rocks of these beds are rather similar. In sandstones mostly fine-grained sand $(0.25-0.1 \mathrm{~mm})$ is predominating which usually forms $50-70 \%$ of the rock. Considerable is the admixture of medium-grained $(0.5-0.25 \mathrm{~mm})$ and very fine-grained $(0.1-0.05 \mathrm{~mm})$ sand fractions which make up $10-30 \%$ and $6-20 \%$ of the rock, respectively. The share of other fractions rarely exceeds $5 \%$ (Fig. 3 ). The

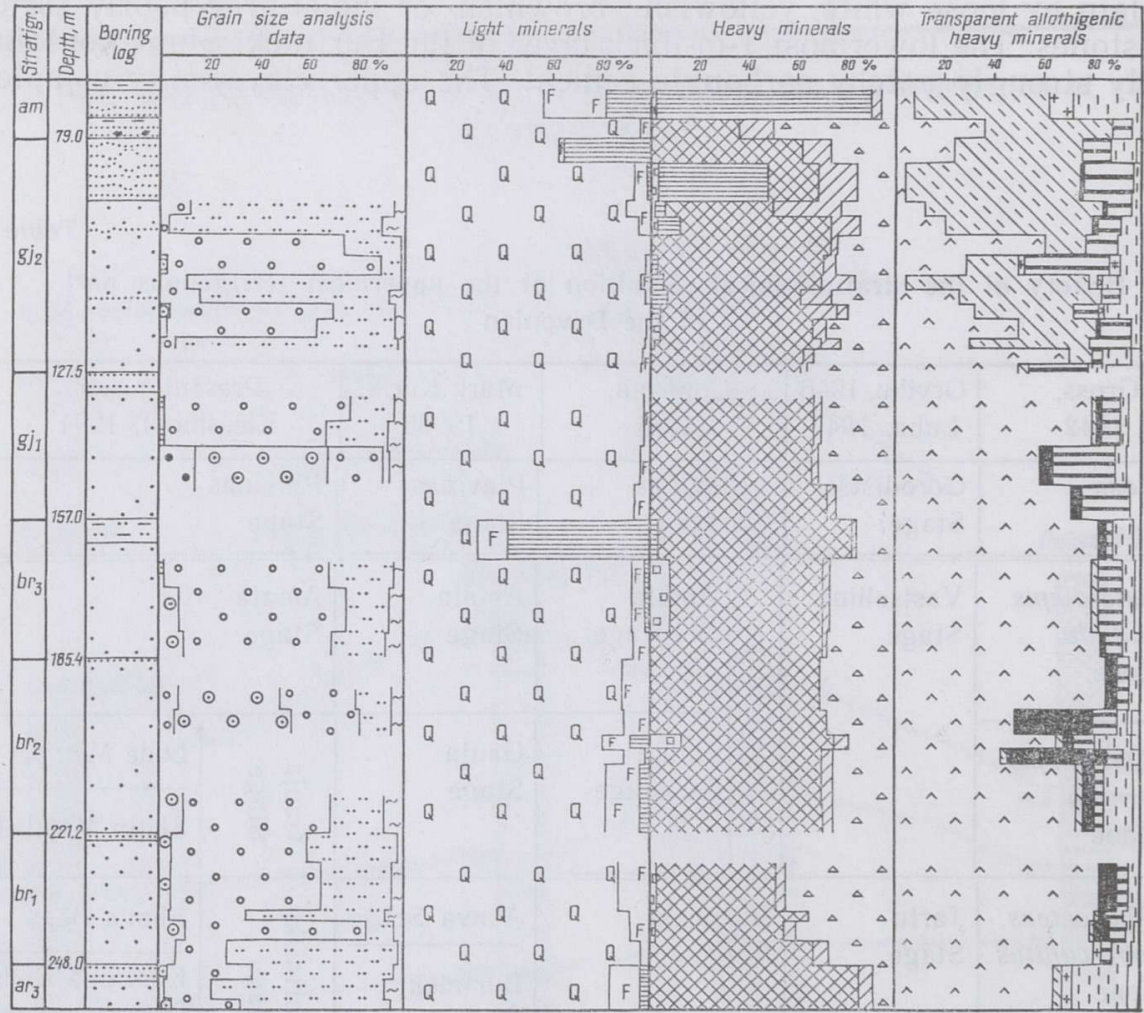

\begin{tabular}{|c|c|c|c|c|c|c|c|c|c|}
\hline .9 & Sandstone & 0 & $F_{r}>0.25 \mathrm{~mm}$ & $\begin{array}{ll}0 & 0\end{array}$ & Quartz & $\infty$ & Ilmenite & Firge & Garnet \\
\hline$\because:$ & Siltstane & 00 & Fr $0.25-0.1 \mathrm{~mm}$ & $F \quad F$ & Feldspar & 12 & Leucoxene & + & Apatite \\
\hline & $\begin{array}{l}\text { Angillitic } \\
\text { slitstane }\end{array}$ & $\begin{array}{lll}0 & 0 \\
\end{array}$ & Fr $0.1-0.05 \mathrm{~mm}$ & & Micas & & $\begin{array}{l}\text { Transparent } \\
\text { allath. minerals }\end{array}$ & & Staur \\
\hline & Clay & \begin{tabular}{|ll} 
& \\
&.. \\
\end{tabular} & Fr $0.5-0.01 \mathrm{~mm}$ & 回 & Pyrite & $n$ & Zircon & * & Kyanite \\
\hline$\rightarrow$ & Pebbles, nodules & $\sim \sim$ & $\mathrm{Fr}<0.01 \mathrm{~mm}$ & 口 & $\mathrm{Fe}$ hydroxides & $\delta$ & Tourmaline & 1,1 & Rutile \\
\hline
\end{tabular}

Fig. 3. Grain size and mineralogical data of the studied stratigraphical interval in the Tsiistre core section. 
predominating thickness of the cross-bedded sandstone series is $20-30 \mathrm{~cm}$. They are dipping to the south, southwest, and southeast, whereas in the Härma Beds the northeast-southwest inclination is prevailing, in the Koorküla and Abava beds, however, the inclination directions are more variable (Fig. 1). Siltstones are mostly medium-cemented, variegated, clays are strongly silty, grey, and reddish-brown.

Mineralogically these sandstones, siltstones, and clays represent oligomictic rocks rich in quartz. In the thoroughly studied very finegrained sand fraction $(0.1-0.05 \mathrm{~mm})$ the quartz content is usually $70-$ $90 \%$, the share of feldspar (mainly orthoclase) is $3-10 \%$, the content of micas (mostly muscovite) is predominantly $1-8 \%$, in mica-rich interbeds sometimes exceeding $50 \%$ (Fig. 3). The guide mineral of the heavy group is ilmenite, the content of which ranges from 45 to $65 \%$. Leucoxene admixture is $5-10 \%$, whereas the amounts of $\mathrm{Fe}$ hydroxides and micas (mostly green biotite) are very variable $(0.1-42 \%$ and $0.1-50 \%$, respectively), the corresponding mean contents being $5-7 \%$ and $9-14 \%$ (Table 2). The share of allothigenic transparent minerals in the heavy fraction is in general 15-30\% (Fig. 3; Table 2). This group is dominated by zircon, which mostly forms $40-70 \%$ of the whole amount. Out of other accessory minerals more important are tourmaline $(7-20 \%)$ and staurolite $(3-15 \%)$. The share of tourmaline is greatest in the Abava Beds, where it makes $10-30 \%$ of the group of transparent allothigenic minerals. Stable contents of more than $5 \%$ have been recorded for garnet, apatite,

Table 2

Mineralogical data of the studied section

\begin{tabular}{|c|c|c|c|c|c|c|c|c|}
\hline \multirow{2}{*}{\multicolumn{2}{|c|}{ Minerals }} & \multicolumn{5}{|c|}{ Stratigraphical level } & \multirow[b]{2}{*}{$\mathrm{gj}_{2}$} & \multirow[b]{2}{*}{ am } \\
\hline & & $\mathrm{ar}_{3}$ & $\mathrm{br}_{1}$ & $\mathrm{br}_{2}$ & $\mathrm{br}_{3}$ & $g j_{1}$ & & \\
\hline $\begin{array}{l}\text { Light } \\
\text { minerals }\end{array}$ & $\begin{array}{l}\text { Quartz } \\
\text { Feldspar } \\
\text { Micas }\end{array}$ & $\begin{array}{r}79.3 \\
12.0 \\
8.7\end{array}$ & $\begin{array}{r}87.4 \\
7.9 \\
4.7\end{array}$ & $\begin{array}{r}85.6 \\
6.6 \\
7.8\end{array}$ & $\begin{array}{r}87.7 \\
6.1 \\
7.2\end{array}$ & $\begin{array}{r}87.7 \\
8.4 \\
3.9\end{array}$ & $\begin{array}{r}91.3 \\
5.2 \\
3.5\end{array}$ & $\begin{array}{r}88.8 \\
7.6 \\
3.6\end{array}$ \\
\hline $\begin{array}{l}\text { Heavy } \\
\text { minerals }\end{array}$ & $\begin{array}{l}\text { Micas } \\
\text { Fe hydroxides } \\
\text { Pyrite } \\
\text { Leucoxene } \\
\text { Ilmenite } \\
\text { Transparent } \\
\text { allothigenic } \\
\text { minerals }\end{array}$ & $\begin{array}{r}11.4 \\
8.8 \\
0.5 \\
7.6 \\
43.4\end{array}$ & $\begin{array}{r}9.0 \\
7.0 \\
\text { bd } \\
8.3 \\
48.7\end{array}$ & $\begin{array}{r}10.2 \\
5.9 \\
0.3 \\
7.3 \\
50.2\end{array}$ & $\begin{array}{r}13.8 \\
4.8 \\
\text { bd } \\
7.3 \\
53.0\end{array}$ & $\begin{array}{r}1.0 \\
8.7 \\
\text { bd } \\
1.5 \\
60.9\end{array}$ & $\begin{array}{r}5.2 \\
0.9 \\
\text { bd } \\
10.5 \\
60.5\end{array}$ & $\begin{array}{r}8.6 \\
10.4 \\
\text { bd } \\
2.5 \\
46.9\end{array}$ \\
\hline $\begin{array}{l}\text { Heavy } \\
\text { transparent } \\
\text { minerals }\end{array}$ & $\begin{array}{l}\text { Zircon } \\
\text { Tourmaline } \\
\text { Garnet } \\
\text { Apatite } \\
\text { Staurolite } \\
\text { Kyanite } \\
\text { Rutile } \\
\text { Titanite }\end{array}$ & $\begin{array}{c}38.2 \\
10.5 \\
21.7 \\
15.6 \\
4.5 \\
0.5 \\
5.8 \\
0.4\end{array}$ & $\begin{array}{c}49.0 \\
14.6 \\
10.2 \\
6.3 \\
9.6 \\
1.4 \\
5.6 \\
0.7\end{array}$ & $\begin{array}{r}49.4 \\
13.9 \\
9.8 \\
5.6 \\
10.0 \\
1.2 \\
6.4 \\
0.7\end{array}$ & $\begin{array}{r}49.3 \\
17.8 \\
7.1 \\
3.9 \\
11.5 \\
1.3 \\
6.4 \\
1.6\end{array}$ & $\begin{array}{r}56.9 \\
4.1 \\
7.0 \\
2.1 \\
16.8 \\
1.6 \\
5.7 \\
0.4\end{array}$ & $\begin{array}{r}38.3 \\
34.7 \\
1.8 \\
2.7 \\
10.2 \\
0.6 \\
9.3 \\
0.4\end{array}$ & $\begin{array}{r}62.3 \\
12.0 \\
0.9 \\
2.5 \\
9.0 \\
1.5 \\
11.6 \\
0.4\end{array}$ \\
\hline Number of $s$ & samples & 153 & 105 & 82 & 58 & 57 & 45 & 25 \\
\hline
\end{tabular}

bd, below detection 
and rutile (Fig. 3; Table 2). The content of apatite and garnet decreases upwards in the section, while that of staurolite increases in the same direction (Figs. 3, 4). Among other heavy transparent minerals more noteworthy are kyanite and titanite. The former is an important accessory mineral which appears in the Burtnieki Stage, occurring lower as an occasional admixture. Higher contents of titanite have been registered in this section for the Abava Beds (Table 2). As casual finds the Burtnieki Stage has yielded amphiboles, pyroxenes, monazite, anatase, and some other minerals.

The clay fraction of the Burtnieki Stage is mineralogically rather uniform showing only slight changes. It consists almost wholly of two minerals, whereas illite (average content 65\%) is always dominating over kaolinite.

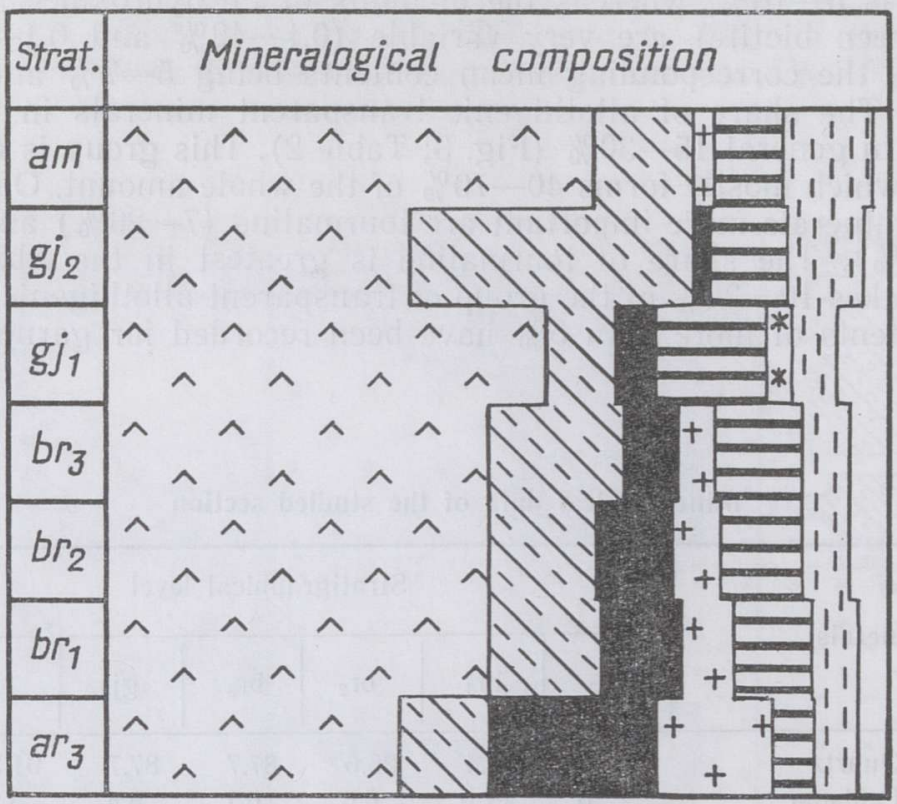

Fig. 4. Mineralogical changes in the vertical section. Legend see Fig. 3.

\section{HÄRMA BEDS $\left(\mathrm{br}_{1}\right)$}

The unit is distributed in southern and southeastern Estonia, where it crops out as a belt expanding eastwards (Fig. 1). The thickness of the Härma Beds is $13.4-28.2 \mathrm{~m}$ and it tends to increase to the east. More famous are the Karksi and Härma outcrops, known as fish localities, also the Tõrva and Helme outcrops in the western part of the distribution area, scarps at the Lutsu Brook and Ahja River in its eastern part. The last outcrops include Suur and Väike Taevaskoda, which serve as favourite sights for tourists. The Härma outcrop, located on the left bank of the Ohne River, $60 \mathrm{~km}$ upstream from the bridge leading to the Härma quarry, suits for the stratotype. Here are exposed yellowish-pink (with white interbeds), fine-grained cross-bedded sandstones with abundant brownish-red interlayers and surfaces, more rarely with mica-rich surfaces. The maximum height of the outcrop is $4.5 \mathrm{~m}$, length $10 \mathrm{~m}$.

The lower boundary of the beds coincides with the boundary of the Aruküla and Burtnieki stages. The topmost part of the Härma Beds is represented by greenish-grey, very fine-grained sand- or siltstone, more 
rarely by a layer of variegated siltstone (Laanemetsa, Valga, VastseKuuste) or clay, which is overlain by light grey or beige fine- to mediumgrained loose sandstone of the Koorküla Beds.

The Härma Beds are mostly represented by yellowish- and pinkishgrey, and white weakly cemented sandstone. Characteristic is the occurrence of numerous Fe hydroxide surfaces and of $1-2-\mathrm{mm}$ - to $5-10-\mathrm{cm}$ thick brownish, more rarely violet, relatively well-cemented small interlayers. In places the Fe hydroxide surfaces are wavy, sometimes forming a reticulate structure in the outcrops. There occur mica surfaces and mica-rich interlayers, clay pebbles, which are often flattened (thickness $0.5-1 \mathrm{~cm}$, diameter up to $10 \mathrm{~cm}$ ), in the Tõrva outcrop also large clay pockets and pebbles (diameter up to $40 \mathrm{~cm}$ ) are found. In the eastern part of the distribution area there are recorded interlayers of sandstone containing patches of carbonate cement.

\section{KOORKÜLA BEDS $\left(\mathrm{br}_{2}\right)$}

The Koorküla Beds have the greatest vertical extent among the subdivisions of the Burtnieki Stage: their thickness in the western part of the distribution area is $20-32 \mathrm{~m}$, in the eastern part $37-42 \mathrm{~m}$. The outcrop area of this unit is relatively narrow (Fig. 1). The best exposures are situated on the banks of the Tilleoja Brook and at Koorküla settlement. The latter is also known as a fish locality and suits well for the stratotype of the beds. The Koorküla outcrop is located on the left slope of the Ohne River valley, about $100 \mathrm{~m}$ upstream from the Koorküla park, where finegrained cross-bedded yellowish-brown sandstones are exposed in a thickness of $5 \mathrm{~m}$. On the same level there occur also the Koorküla caves, situated $150 \mathrm{~m}$ downstream on the same slope of the valley, where the maximum thickness of the section is $4 \mathrm{~m}$. The Koorküla Beds are everywhere underlain by the Härma Beds, their topmost part is usually represented by variegated siltstone, more rarely by grey siltstone or multicoloured clay, which are overlain by white, light grey, beige or pinkish sandstone of the Abava Beds.

The predominating rock type of the Koorküla Beds is light grey, yellowish-grey, yellowish-white, more rarely pinkish or reddish weakly to medium-cemented fine-grained cross-bedded sandstone. The sandstone contains irregular rust-brown interlayers, rust nodules, mica-rich surfaces. Characteristic is the occurrence of numerous thin $(0.5-5 \mathrm{~cm})$ siltstone interbeds. The total share of siltstone and clay is mostly $2-20 \%$, in the western part of the distribution area (Karula-Valga-Tõrva) $40-50 \%$, whereas in the last region clay forms $10-20 \%$ of the section. Thicker $(1-4 \mathrm{~m})$ siltstone and clay layers occur in the middle and upper parts of the section.

Siltstone is predominantly lumpy, variegated, with bluish, violet-grey, reddish-brown, and tobacco colouring. More rarely there occur platy grey and brown siltstones. Clay is strongly silty, fine-grained, grey or reddish.

\section{ABAVA BEDS $\left(\mathrm{br}_{3}\right)$}

In Latvia Liepinš (Лиепиньш, 1960) distinguished the Abava Formation in the upper part of the Burtnieki Stage, where it comprises the socalled "transitional beds" of Gross (1942). Since the 1960s, after detailed study of the fish fauna and its burial pattern in the Lejei outcrop at the Abava River, Ljarskaja (Лярская, 1966) ascribed this level to the Gauja Stage, considering here the Burtnieki fauna as redeposited. On the basis 
of fish finds the analogues of these beds have been recorded in Lithuania (Нарбутас, 1964), as well as in Estonia at the Võhandu River (Курик et al., 1989). This fauna is also known from the sections of Scotland, France, China, and Severnaya Zemlya, on the basis of which Mark-Kurik (1993a, 1993b) has treated the Abava Beds in the rank of a stage (Table 1). Still, this view has not yet been accepted by other Baltic Devonian explorers.

Considering the characteristic features of the outcrops situated at the Vōhandu River, also the data of mineralogical analysis of rocks from the Lejei outcrop, the Abava Beds are in the present paper assigned to the Burtnieki Stage as its upper part. The thickness of the Abava Beds in Estonia ranges from $15.1 \mathrm{~m}$ to $32 \mathrm{~m}$. The outcrop area widens in the western direction (Fig. 1). The best outcrops are situated at the Võhandu River, including the Essi outcrop, which is known as a fish locality and suits for the stratotype of this level in Estonia. The Essi outcrop is located on the left bank of the Vōhandu River at the Essi farm. Here areally for about $7 \mathrm{~m}$ there are exposed up to 2 -m-thick whitish- to pinkish-yellow cross-bedded sandstones. The bed surfaces show often the occurrence of clay pebbles.

In the complete sequence the Abava Beds are everywhere underlain by the Koorküla Beds and overlain by the Gauja Stage. The topmost part of the Abava Beds is usually represented by variegated (mostly violet-grey) or grey argillaceous siltstone, which is overlain by pinkish or white varigrained sandstone of the Gauja Stage. On the immediate contact these rocks often contain carbonate cement.

The predominating rock type in the Abava Beds is white, yellowish-, and pinkish-grey, more rarely medium-brown and weakly cemented finegrained cross-bedded sandstone. There occur also sandstone interbeds with abundant carbonate cement, whereas cementation may often be irregular. Such interbeds are more frequent in the western part of the distribution area. Typical are pebbles of grey, more seldom reddish-brown clay with a thickness of about $1-2 \mathrm{~cm}$, sometimes up to $5 \mathrm{~cm}$, and scattered quartz grains (diam. $1-2 \mathrm{~cm}$ ). Rarely there are recorded Fe hydroxide-rich concretions, surfaces, and thin lens-shaped mica-rich interlayers. Compared to the lower members, the share of siltstone has somewhat increased in the Abava Beds. On average siltstone forms $27 \%$ of the section of the beds, in the Petseri-Dekshino region 53-65\%. The siltstone may be fine-grained grey and greenish-grey, as well as lumpy and variegated (predominantly violet-grey). The share of clays in the section is $4 \%$. Mostly there occur highly silty violet-grey, more rarely reddish-brown clays. The Laanemetsa, Luutsniku, and Hino core sections show also interlayers of dolomite (predominantly nodular) and variegated domerite.

\section{GAUJA STAGE (gj)}

The Gauja Stage was formally established by Liepinš (1951), although the corresponding stratigraphical level existed already in the scheme of Kraus (1934) and had been distinguished by Gross (1942, Table 1). At different periods it has been treated as a separate stage or as forming one stage together with the Amata Stage (Table 1). The stratotype of the Gauja Stage lies at the Gauja River in northern Latvia between Cesis and Sigulda. In Estonia more important outcrops are located at the Piusa River, Tuhkvitsa Brook, Pärlijōe River. The glass sand quarries near the Piusa railway station are located in the Gauja Stage, where the profile of the stage can be well observed in abandoned quarry trenches.

The total extent of the stage, which in Estonia is $78-90 \mathrm{~m}$, is pen- 
etrated by a few boreholes. It is distributed only in a restricted area in southeastern Estonia (Fig. 1) and lies everywhere on the Abava Beds of the Burtnieki Stage (Fig. 2). The stage is overlain by the Amata Stage: on the grey clay or siltstone layer of the topmost Gauja Stage there occurs the breccia-like poorly sorted rock of the Amata Stage. The clayey-sandy rock contains pebbles of strongly cemented siltstone and sandstone up to $2-5 \mathrm{~cm}$ in size. The thickness of this layer may be a couple of metres.

The Gauja Stage is dominated by weakly to medium-cemented light- to yellowish-grey, more rarely light brown, pinkish-brown or variegated cross-bedded sandstones. The cross-bedded series are $5-40 \mathrm{~cm}$, mostly $15-30 \mathrm{~cm}$ thick, predominating are inclinations to the southwest, south, and southeast. The sandstones are fine-grained, whereas the share of fine-grained sand particles $(0.25-0.1 \mathrm{~mm})$ is usually $55-65 \%$, the admixture of very fine-grained sand $(0.1-0.05 \mathrm{~mm})$ makes on average $22.5 \%$. The content of medium-grained sand $(0.5-0.25 \mathrm{~mm})$ exceeds rarely $10 \%$, other grain size classes occur in inconsiderable amounts. The sandstone contains brown iron-rich surfaces, which are branching in a complicated way, pebbles of violet-brown and grey clay (diam. up to $10 \mathrm{~cm}$ ), quartz (diam. up to $4 \mathrm{~cm}$ ), and Fe hydroxide (diam. $2-3 \mathrm{~mm}$ ).

Siltstones form on average $17 \%$, clays $15 \%$ of the section and occur predominantly in its upper half (Figs. 2, 4). The siltstones are often clayey, represented by variegated (reddish-brown, violet-grey, and with grey shades), as well as horizontally fine-bedded grey and brownish varieties. Clays are strongly silty, grey, and violet-grey, often dolomitic.

In the section of the Gauja Stage two cyclic complexes can be distinguished. The lower complex is mostly represented by sandstones, a layer of grey or variegated siltstone occurs usually in the topmost part. The lower part of the thicker upper complex is represented by light, mainly white sandstones, its upper part is dominated by siltstones and clays (Fig. 2). These parts of the Gauja Stage correspond to the Sietin and Lode members established by Kuršs (Kуршc, 1992) in northern Latvia. These are distributed in a restricted area in southeastern Estonia, northeastern Latvia, in the western part of the Pskov Region and southern part of the Leningrad Region, and cannot be distinguished palaeontologically. In Estonia the Sietin $\left(g j_{1}\right)$ and Lode $\left(g j_{2}\right)$ members are clearly separated on the basis of mineralogical characters (Figs. 3, 4; Table 2).

Mineralogically the clastic sediments of the Gauja Stage are quartzrich oligomictic rocks with the quartz content in very fine sand amounting to $80-94 \%$, the share of feldspar (mainly orthoclase) is $3-10 \%$, micas (mostly muscovite) form 20-30\%. The heavy fraction is dominated by ilmenite, transparent allothigenic minerals make up $20-30 \%$. In the last group the key mineral is zircon, although in the Lode Member tourmaline often dominates over zircon. Among other minerals we could point out staurolite and rutile, more rarely there occur apatite and kyanite (Figs. 3, 4; Table 2). The Sietin and Lode members are mostly distinguished on the basis of the mineralogical composition of the heavy fraction, whereas in the light fraction only a slight quartz maximum has been recorded in the Lode Member. Considering the general spectrum of the heavy fraction, the content of $\mathrm{Fe}$ hydroxide is higher in the Sietin Member and the share of leticoxene is greater in the Lode Member (Fig. 3; Table 2). Apart from the aforementioned high content of tourmaline in the Lode Member, the group of allothigenic minerals of the heavy fraction shows the predominance of staurolite, garnet, and kyanite in the rocks of the Sietin Member and increase of the rutile content in the sediments of the Lode Member (Figs. 3, 4; Table 2). The two parts of the Gauja Stage differ notably in the mineralogical composition of the clay fraction. If in the lower member the average share of hydromica is $75 \%$ and that of kaolinite is $25 \%$, then 
in the upper part the corresponding values are $45 \%$ and $55 \%$. The Lode Member is the most kaolinite-rich level in the Devonian sequence of Estonia.

\section{AMATA STAGE (am)}

In the rank of a stage this level was distinguished by Liepinš (1951), although as a stratigraphical unit it appeared already in the schemes of Kraus (1934) and Gross (1942; Table 2). The stratotype of the stage is situated at the Amata River in Latvia. In Estonia the outcrop of the stage comprises a restricted area in southeastern Estonia (Fig. 1). The complete section of the stage has been recorded only in some boreholes, where its thickness ranges from 12 to $21 \mathrm{~m}$ (Fig. 2). In the outcrops on the banks of the Piusa River its extent reaches $30 \mathrm{~m}$, in Latvia $20-30 \mathrm{~m}$. Besides the Piusa River, the outcrops of the Amata Stage occur also at Mustajõe, at the Peetri River, and in the vicinity of Vastseliina. The stage lies everywhere on the grey clay of the Gauja Stage and starts with a layer of breccia-like sand. By the data of Kuršs (Kуршc, 1992), in the lower Amata layers the cross-bedded series are inclined to the north, which is uncharacteristic of this part of the Devonian. The stage is overlain by dolomites or dolomitic clays of the Plavinas Stage (pl) which lie on the variegated dolomitic, strongly silty clay of the topmost layer of the Amata Stage.

In Estonia the Amata Stage is represented by sandy-silty sediments, which alternate with frequent clay interbeds. By borehole data the predominating rock type is greenish- and violet-grey siltstone, which forms on average $45 \%$ of the section. The average share of sandstones in the cores is $26 \%$, whereas in outcrops they are predominating. The sandstones of the Amata Stage are light to yellowish-grey, more rarely reddishbrown, fine-grained, medium- to strongly cemented, with indistinct crossbedding, the inclination of which varies in wide limits. The interbeds are represented by highly shaly sandstones. The sandstones contain often pebbles and lens-shaped interlayers of clay, more rarely quartz pebbles.

The clays form on average $29 \%$ of the section. Clay interlayers are usually violet-grey and -brown, beds of grey clay are more rare.

The mineralogical composition of the sandy-silty sediments of the Amata Stage shows large amounts of quartz. The quartz content in very fine sand particles is $80-90 \%$, feldspars form $5-10 \%$, micas $2-9 \%$. The heavy mineral suite is dominated by ilmenite, the share of transparent allothigenic minerals is relatively great $(26-40 \%)$, considerable but varying is the admixture of Fe hydroxide and micas (Table 2). Among transparent allothigenic minerals zircon is predominating. It is followed by tourmaline, staurolite, and rutile in almost equal amounts, whereas the content of other minerals is insignificant (Figs. 3, 4; Table 2). Somewhat exceptional is the Tsiistre section, where the last group is dominated by tourmaline, on one level by apatite (Fig. 4).

The assemblage of clay minerals is dominated by hydromicas with the average content of $95 \%$. In small amounts there occurs kaolinite but other clay minerals are almost missing.

\section{CONCLUSIONS}

The upper sandy complex of the Devonian of Estonia is mostly characterized by the sediments deposited in the nearshore belt of a shallow marine basin and in a delta, whereas the sedimentation was interrupted 
by gaps. The alteration of conditions has a cyclic nature: the six levels, distinguished in the part of the section studied, correspond to the stages of natural development. At that, up to the end of Gauja age, the general tendency has been the shallowing of the marine basin, which at the beginning of Amata age was replaced by its deepening. The conditions became more complicated and variable at the end of Burtnieki age, when the so far more or less definite inclinations of cross-bedded series turned irregular.

The influx of the clastic material was mostly from the north. Constant addition of new material is proved by the persistent growth of the content of staurolite, one of the key minerals in metamorphosed rocks, from the beginning of the Burtnieki Stage, where it appears in our section, up to the Lode Member of the Gauja Stage, where it is supplemented by certain amounts of kyanite associating with staurolite in metamorphosed rocks (Fig. 4; Table 2). Regular changes in the mineralogical composition of the upper terrigenous complex of the Devonian show that since the deposition of this complex at the Tarvastu time of Aruküla age $\left(\mathrm{ar}_{3}\right)$, the aforementioned increase in the staurolite (and kyanite) content was accompanied by constant growth of zircon, tourmaline, and rutile contents, and decrease in the amount of apatite and garnet (Fig. 4; Table 2). Roundness of the clastic material and the amount of quartz have increased in the same direction. This indicates the ever growing influence of redeposition processes together with intense weathering, which is confirmed by continuous growth of the ilmenite content beginning from the upper part of the Aruküla Stage (Kleesment, 1994). The effect of redeposition and local weathering processes was particularly great in the second half of Gauja age, when there probably occurred a notable gap in sedimentation. This is the level of kaolinite maximum in the Devonian sequence of Estonia. High contents of zircon and rutile in the Amata Stage show that redeposited material is important on this level as well, but local weathering has become less significant: the share of kaolinite has decreased sharply, that of zircon less notably.

The mineralogical character of rocks and regular changes in it established in the course of investigations, help us to distinguish the layers under consideration in sections, as the finds of fossils are rare in this part of the Devonian sequence.

\section{ACKNOWLEDGEMENTS}

The author expresses her thanks to D. Kaljo and E. Pirrus for helpful comments on the text, to A. Noor for linguistic improvements, and to $\mathrm{K}$. Ronk for the figures.

The research was made possible in part by grant No. 314 from the Estonian Science Foundation.

\section{REFERENCES}

Gross, W. 1940. Uber das Devon der russischen Tafel. - Geol. Rundschau, 31, 2, 7/8, $525-547$.

Gross, W. 1942. Fischfaunen des baltischen Devons und ihre biostratigraphische Bedeutung. - Korrespondenzbl. Naturf. Riga, 64, 376-436.

Klapper, G., Feist, R. and House, M. R. 1987. Decision on the Boundary Stratotype for the Middle/Upper Devonian Series Boundary. - Episodes, Ottawa, 10, 2, 97-101. 
Ǩleesment, A. 1994. Subdivision of the Aruküla Stage on the basis of lithological and mineralogical criteria. - Proc. Estonian Acad. Sci. Geol., 43, 2, 57-68.

Kraus, E. 1934. Die Gliederung des baltisch-russischen Altrotsandsteins. - Zeitschr. Deutsch. Geol. Ges., 36, 213-234.

Liepinš, P. 1951. Dazi devons stratigrafijas jautajumi Galvena devona lauka rietumu dala. - Latv. PSR ZA Vestis, 6, 983-986.

Luha, A. 1946. Eesti NSV maavarad. Tartu.

Mark-Kurik, E. 1993a. Givetian and the base of the Frasnian in the Baltic area. Abstracts of the Second Baltic Stratigraphic Conference. Vilnius, 57.

Mark-Kurik, E. 1993b. Walter Gross and Baltic Devonian biostratigraphy. - The Gross Symposium Scientific Sessions. Abstracts. Göttingen.

Orviku, K. 1946. Tartu linna hüdrogeoloogia. - TRU Toimetised, Geoloogia ja Geograafia, 1 .

Rzhonsnitskaya, M. A. 1988. Biostratigraphic scheme of the Devonian of the Russian platform. - Devonian of the World. Calgary, III, 691-701.

Курик Э., Куршс В., Лярская Л. 1989. Граница среднего и верхнего девона в районе устья р. Абава (Латвия). - Изв. АН ЭССР. Геол., 38, 4, 162-165.

Куршс В. М. 1975. Литология и полезные ископаемые терригенного девона Главного поля. Зинатне, Рига.

Куршс В. М. 1992. Девонское терригенное осадконакопление на Главном девонском поле. Зинатне, Рига.

Лиепиньш П. П. 1960. Девонская система. - In: Геология СССР, 38. Москва, $61-86$.

Лярская Л. А. 1966. К вопросу о границе между средним и верхним девоном в Латвии. - In: Палеонтология и стратиграфия Прибалтики и Белоруссии. Вильнюс, $281-286$.

Марк Э. Ю. 1958. О некоторых вопросах стратиграфической номенклатуры девона северо-запада Главного поля. - Изв. АН ЭССР. Сер. техн. и физ.-матем. наук, $7,4,348-349$.

Марк Э. Ю., Паасикиви Л. Б. 1960. Девонская система. - In: Геология СССР, 28. Москва, 146-166.

Нарбутас В. В. 1964. Стратиграфия и литология раннефранских отложений Польско. Литовской синеклизы в свете фациальной зональности франского бассейна на северо-западе Русской платформы. - In: Вопросы стратиграфии и палеогеографии девона Прибалтики. Минтис, Вильнюс, 89-104.

Обручев Д. В. 1951. О границе между средним и верхним девоном на Главном поле. - Докл. АН СССР, 28, 5, 981-984.

Ржонсницкая М. А., Куликова В. Ф. (eds.). 1990. Решения межведомственного регионального стратиграфического совещания по среднему и верхнему палеозоі Русской платформы. Девонская система. Ленинград.

Сорокин В. С. (ed.). 1981. Девон и карбон Прибалтики. Зннатне, Рига.

\section{EESTI DEVONI ULEMISE TERRIGEENSE KOMPLEKSI LITOLOOGILINE ISELOOMUSTUS}

\section{Anne KLEESMENT}

On antud Givet' ladejärgu Burtniehi, Gauja ja Amata lademe leviku seaduspärasused ja litoloogilis-mineraloogiline iseloomustus Eestis. Läbilõike tsüklilise ehituse alusel on Burtnieki lademe puhul eraldatud kolm üksteisel lasuvat üksust: Härma, Koorküla ja Abava kihid. Gauja lademe läbilõikes eristuvad aga Lätis eraldatud Sietini ja Lode kihistik. On esitatud kõikide käsitletud üksuste iseloomustus ja väljaeraldamise kriteeriumid. 


\section{ЛИТОЛОГИЧЕСКАЯ ХАРАКТЕРИСТИКА ВЕРХНЕГО ТЕРРИГЕННОГО КОМПЛЕКСА ДЕВОНА ЭСТОНИИ}

\section{Анне КЛЕЕСМЕНТ}

Дана литолого-минералогическая характеристика и определены закономерности распространения отложений буртниекского, гауяского и аматаского горизонтов в Әстонии. На основе цикличного строения разреза в буртниекском горизонте выделены три последовательно залегающих слоя: Хярма, Кооркюла и Абава. В разрезе гауяского горизонта прослежены выделенные в Латвии сиетинская и лодеская пачки. Приведены критерии выделения описанных подразделений. 